\title{
In Memoriam: Donald A. Smith (29 August 1930-13 November 2020)
}

Don Smith, long-time Ottawa Field-Naturalists' Club (OFNC) member, Council Member, Vice-President, Recording Secretary, and events speaker, died at his family home near Stittsville, Ontario, at age 90. He was the first Interpretation Specialist at E.C. Manning Provincial Park, British Columbia, hired by R. Yorke Edwards, whose tribute was published in the previous issue of The Canadian Field-Naturalist (CFN; Cannings et al. 2020). He was a professor in biology at Carleton University and curator of the Museum of Zoology (1957-1995), having completed his Ph.D. at University of Toronto in 1957. He also served as the Assistant Editor of CFN (1972-1981). A full tribute is planned for an upcoming issue of CFN.

\section{Acknowledgements}

Thanks to Fenja Brodo for sharing Don's obituary from The Ottawa Citizen and her tribute to Don expected to be published in an upcoming issue of Trail $\&$ Landscape, the Ottawa regional OFNC publication.

\section{Literature Cited}

Cannings, R.A., T. Goward, and W. J. Merilees. 2020. Tribute to R. Yorke Edwards, 1924-2011. Canadian Field-Naturalist 134: 270-294. https://doi.org/10.22621/ cfn.v134i3.2657

D.A.W. LEPITZKI CFN Editor-in-Chief

(C) The author. This work is freely available under the Creative Commons Attribution 4.0 International license (CC BY 4.0). 